\title{
Black Box Testing in Web-based Applications: Case Study - Remedial Application at Manado State Polytechnic
}

\author{
Harson Kapoh \\ Dept. of Information \\ Technology State Polytechnic of \\ Manado, Indonesia
}

\author{
Olga E. Melo \\ Dept. of Information \\ Technology State Polytechnic of \\ Manado, Indonesia
}

\author{
Anthon A. Kimbal \\ Dept. of Information \\ Technology State Polytechnic of \\ Manado, Indonesia
}

\begin{abstract}
The teaching and learning process at Manado State Polytechnic is assisted by an online learning process. At the end of the learning process there are still students who have not passed one or more courses. The passed categories are passed, passed the experiment and did not pass. If the student passes the experiment, the student can follow a process of improvement known as remedial. The remedial process is usually done manually. Currently an online system has been developed for this remedial process. The online remedial process is urgently needed at this time because the Covid-19 pandemic has not ended. The system built to assist the remedial process is to use a web-based system. This system can accommodate the need to register for students who need improvements in the courses to be taken. This system is used by students, lecturers and admins. Software testing is needed so that the software can work in accordance with the expected functionality and can be truly ready to be implemented. Testing is done using the Black Box method where this method will test without paying attention to the structure of the program to be tested. Black Box testing is carried out on this web-based remedial software, carried out on a laboratory scale with real data to produce quality software because its functions can produce or process data as expected.
\end{abstract}

\section{General Terms}

Software Testing

\section{Keywords}

Test, black box, remedial, web

\section{INTRODUCTION}

The teaching and learning process at Manado State Polytechnic is assisted by an online learning process. At the end of the learning process there are still students who have not passed one or more courses. The passed categories are passed, passed the experiment and did not pass. If the student passes the experiment, the student can follow a process of improvement known as remedial.

The remedial process is usually done manually. Currently an online system has been developed for this remedial process. The online remedial process is urgently needed at this time because the Covid-19 pandemic has not ended yet [1].

The remedial process is usually taken by students after students know that their status is passing the experiment. Students will register with the admin managing remedial and will get remedial documents according to the number of courses that the student will improve.

The system built to assist the remedial process is to use a web- based system. This system can accommodate the need to register for students who need improvements in the courses to be taken. This system is used by students, lecturers and admins.

Software testing is needed so that the software can work in accordance with the expected functionality and can be truly ready to be implemented. Testing is done using the Black Box method where this method will test without paying attention to the structure of the program to be tested [2].

This software contains several modules that will be tested for functionality so that the software can match the specifications.

\section{THEORY}

\subsection{Testing}

Software testing is to determine the extent of software quality assurance and this is a representation of the main study of specifications, design, and coding. This test requires knowing the critical elements of the software so that the quality of the software is known.

The objectives of the test are

1. The process of executing a program with the intention of finding errors [3]

2. A good test case is a test case that has a high probability of finding errors that have never been found before

3. A successful test is a test that reveals all errors that have not been found before.

\subsection{Black-box Testing}

Black-Box Testing is a software testing technique that focuses on the functional specifications of software [4], [5]. Blackbox Testing works by ignoring the control structure so that attention is focused on domain information [5]. Blackbox Testing the set of input conditions that will train all the functional requirements of a program [6], [5]. The advantages of using the Blackbox Testing method are [7]: (1) Examiners do not need to have knowledge of a particular programming language; (2) Testing is carried out from the user's point of view, this helps to reveal ambiguities or inconsistencies in the specification of requirements; (3) The programmer and the tester both depend on each other. The shortcomings of the Blackbox Testing method are [7]: (1) Test cases are difficult to design without clear specifications; (2) The possibility of having a repeat of a test that the programmer has already performed; (3) Some parts of the back end are not tested at. 


\section{TESTING METHOD}

\subsection{Testing Phase}

This test requires stages, the testing stages are as follows:

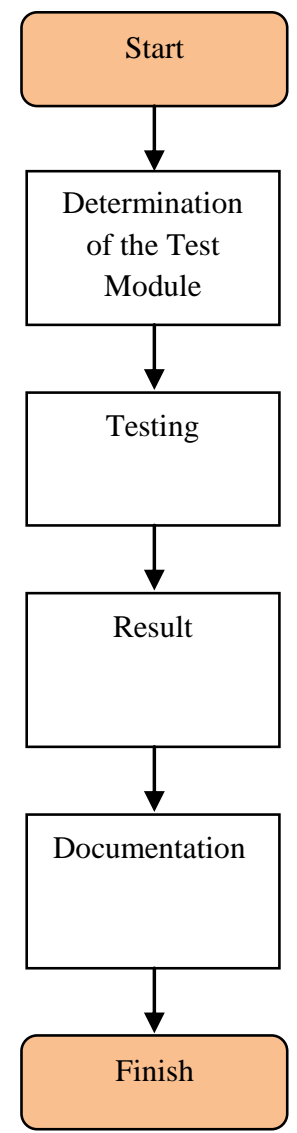

Fig 1: Testing Flow Chart

The testing stage is required in this study. The stage begins with determining the test module, then testing using a Black Box to see whether the functions of the software or module can run well with the expected results and then the results are documented so that they can be re-evaluated. (See figure 1).

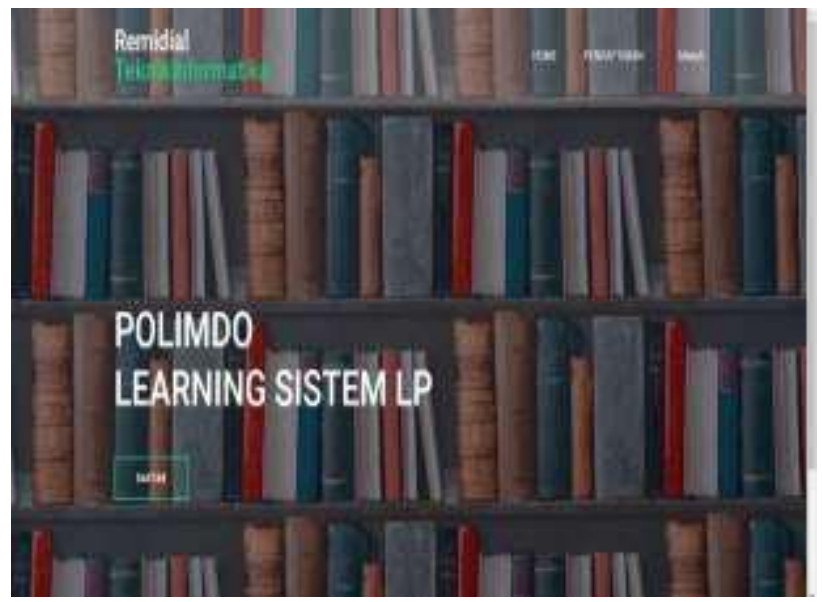

Fig 2: Home Page

The Home Page is the home page of the remedial system which has a menu for a list of courses that will be corrected by the student concerned (see figure 2). Students can fill in the courses that will be improved. The results of the filling in from students will be validated first by the admin and if it has been validated (see figure 4 ).

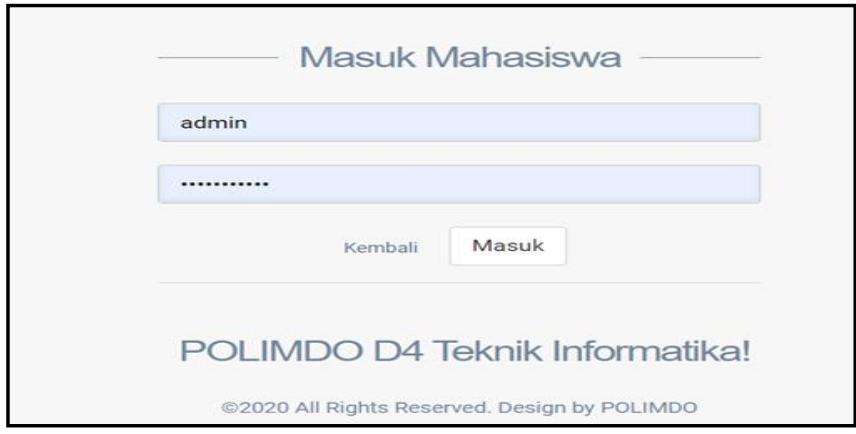

Fig 3: Login Page

The login page is the login page that students use to make improvements and also communicate with lecturers in the course (see figure 3 ).

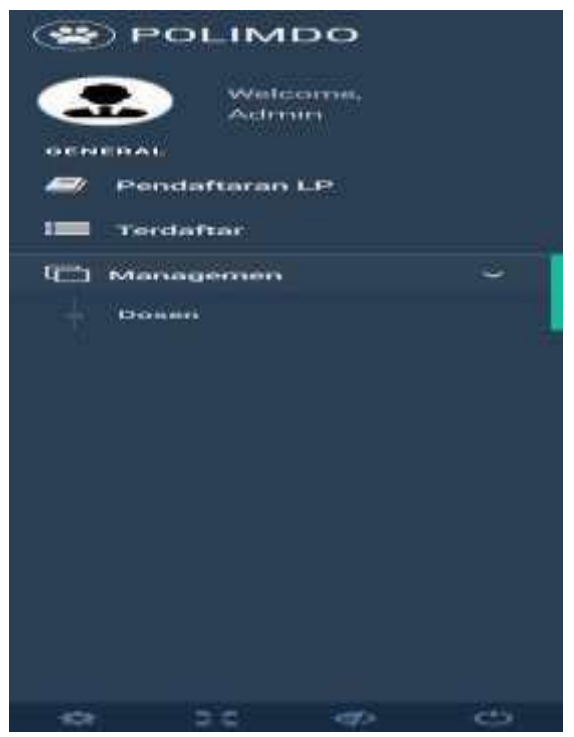

Fig 4: Admin Page

Lecturer page is a page that is used by lecturers to communicate with students to improve their courses. In this section there is a list of courses that will be corrected by students (see figure 5 ).

The database is a data storage area that is owned by the system to store data and retrieve data for testing purposes (see figure 6).

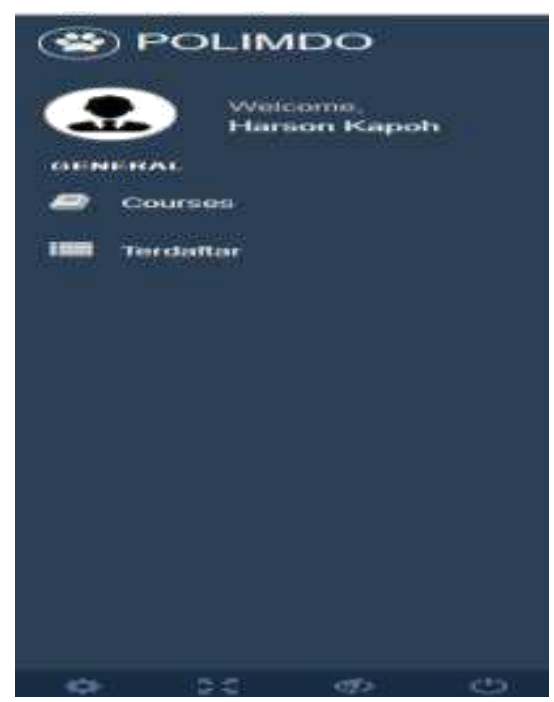

Fig 5: Halaman Dosen 


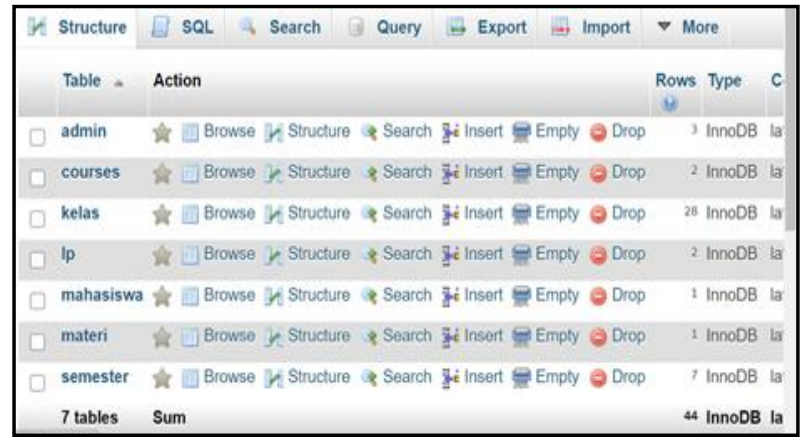

Fig 6: Database

\section{RESULT AND DISCUSSION}

\subsection{Result}

Web testing consists of a testing table for each form which is divided above. Description is the parts that will be tested, the goal-sharing scenario, the expected result expectation and the actual result whether it matches the expected result. Here is a web test table.

Tabel 1. Student Side Test Summary

\begin{tabular}{|l|l|l|l|l|}
\hline S. No. & $\begin{array}{l}\text { Descriptio } \\
\mathbf{n}\end{array}$ & Scenario & Expectation & Actual result \\
\hline 1 & $\begin{array}{l}\text { LP Student } \\
\mathrm{n}\end{array}$ & Registratio & $\begin{array}{l}\text { Input data } \\
\text { students and mk, } \\
\text { value and name } \\
\text { Lecturer }\end{array}$ & Corresponding \\
\hline 2 & Login & $\begin{array}{l}\text { Enter username and } \\
\text { password (if already } \\
\text { registered) }\end{array}$ & $\begin{array}{l}\text { Go to view } \\
\text { courses }\end{array}$ & Corresponding \\
\hline 3 & Courses & Enter the code & Download co & Corresponding \\
\hline
\end{tabular}

Tabel 2. Admin Side Test Summary

\begin{tabular}{|l|l|l|l|l|}
\hline $\begin{array}{l}\text { S. } \\
\text { No. }\end{array}$ & Description & Scenario & Expectation result & Actual result \\
\hline 1 & Login & Input login (if truer) & Go to view Main & Corresponding \\
\cline { 2 - 5 } & Input login (if false) & Stay in view Login & Corresponding \\
\hline 2 & Validasi & $\begin{array}{l}\text { Validate Students } \\
\text { (already registered) }\end{array}$ & $\begin{array}{l}\text { The student has } \\
\text { registeredand will } \\
\text { follow the process } \\
\text { Remedial }\end{array}$ & Corresponding \\
\hline 3 & $\begin{array}{l}\text { Lecturer } \\
\text { Management }\end{array}$ & - & Input data of Lecturer & Corresponding \\
\hline
\end{tabular}

Tabel 3. Lecturer of Side Test Summary

\begin{tabular}{|l|l|l|l|l|}
\hline $\begin{array}{l}\text { S. } \\
\text { No }\end{array}$ & Description & Scenario & Expectation result & Actual result \\
\hline 1 & Login & $\begin{array}{l}\text { Input login (if } \\
\text { truer) }\end{array}$ & Go to view Main & Corresponding \\
\cline { 3 - 5 } & $\begin{array}{l}\text { Input login (if } \\
\text { false) }\end{array}$ & Stay in view Login & Corresponding \\
\hline 2 & Courses & $\begin{array}{l}\text { Entering data } \\
\text { remedial To } \\
\text { Students }\end{array}$ & $\begin{array}{l}\text { Will input material for } \\
\text { LP students }\end{array}$ & Corresponding \\
\hline
\end{tabular}


Testing that has been carried out uses a procedure that starts with determining the module to be tested and testing starts from the side of the student who registers to the remedial process, the admin side also starts from the login, as well as the lecturer starting from the login to the remedial process. The results show that the software is as expected.

\subsection{Discussion}

Black Box testing is a test that is applied in this study, namely the functions that exist in the software without paying attention to scripts or program codes [2]. For this reason, the testing that has been carried out also focuses on testing existing functions with an emphasis on that existing input can be accepted by the software and the resulting output is in accordance with expectations, so this web-based remedial software is quality software.

Black Box testing shows that this web-based remedial software is of high quality with the results as expected and this shows that the software functions are working according to specifications and shows that the performance requirements have been met.

Tests carried out on this software are still at a prototype scale in the laboratory, so the results of the test are not known if they are carried out at different places on an integrated web system. This test is necessary because it may happen that some functions will not work as expected.

\section{CONCLUSION}

Black Box testing is carried out on this web-based remedial software, carried out on a laboratory scale with real data to produce quality software because its function can produce or process data as expected. It is hoped that later integrated testing can be carried out in real time in different locations so as to produce a ready-to-use application through performance testing using the appropriate sample.

\section{ACKNOWLEDGMENTS}

Thanks to the Manado State Polytechnic for allowing and assisting the research was conducted.

\section{REFERENCES}

[1] Kapoh, Harson And Melo, Olga E And Kimbal,2020, Model Digital Sistem Administrasi Dan Proses Remedial Di Program Studi D4 Teknik Informatika Di Politeknik Negeri Manado\}, Prosiding Seminar Nasional Terapan Riset Inovatif (Sentrinov) $\}$, Volume $=6$, Number $=1$, Pages $=869--877$.

[2] H. Kapoh, E. S. Lumunon and N. A. E. Sajangbati, "Design model material requirement of coconut flour production and performance testing based multi user in North Sulawesi," 2016 International Conference on Knowledge Creation and Intelligent Computing (KCIC), Manado, 2016, pp. 1-7, doi:10.1109/KCIC.2016.7883617..

[3] R.Pressman, 2010, Software Engineering.

[4] S. Roohullah Jan, S. Tauhid Ullah Shah, Z. Ullah Johar, Y. Shah, and F. Khan., 2016. An Innovative Approach to Investigate Various Software Testing Techniques and Strategies. Int. J. Sci. Res. Sci. Eng. Technol., vol. 2, no. 2, pp. 682-689.

[5] J. Watkins., 2001. Testing IT An Off The Shelf Software Testing Process.

[6] A. Bansal., 2014. A Comparative Study of Software Testing Techniques. Int. J. Comput. Sci. Mob. Comput., vol. 36, no. 6, pp. 579-584.

[7] P. Ammann, J. Offutt, and I. Version., 2016. Introduction to Software Testing Edition 2 Paul Ammann and Jeff Offutt Instructor Version. pp. 2002-2009. 